\title{
Development of molecular method for sex identification in date palm (Phoenix dactylifera L.) plantlets using novel sex-linked microsatellite markers
}

\author{
Maryam $^{1}$ - Muhammad Jafar Jaskani ${ }^{1}$ - Faisal Saeed Awan ${ }^{2}$. \\ Saeed Ahmad ${ }^{1}$ Iqrar A. Khan ${ }^{1}$
}

Received: 17 April 2015/Accepted: 13 June 2015/Published online: 9 January 2016

(c) The Author(s) 2016. This article is published with open access at Springerlink.com

\begin{abstract}
Microsatellite markers containing simple sequence repeats (SSRs) are a valuable tool for genetic analysis. Date palm is a dioecious and slow flowering and is very difficult to identify the gender of the trees until it reaches the reproductive age (5-10 years). A total of 12 microsatellite primers were used with 30 date palm samples, 14 parents ( 8 male +6 females) and 16 progeny (developed from parents breeding) which showed that microsatellites were highly polymorphic, having a great number of alleles. A total of 124 alleles were characterized in 12 SSR loci. On average, there are 9.08 alleles per locus, with a range from 5 to 16 alleles, for primers mpdCIR 15 and mpdCIR57, respectively. These primers produced 15 polymorphic loci specifically in male date palm samples and the seedlings harboring the unique fragments were further characterized as male plants. Increasingly, $38.46 \%$ of these loci were scored as homozygous alleles while
\end{abstract}

All the authors contributed equally to this work.

Muhammad Jafar Jaskani

jjaskani@uaf.edu.pk

Maryam

maryamuaf1472@gmail.com

Faisal Saeed Awan

awanfaisal@yahoo.com

Saeed Ahmad

sandhu100hasan@yahoo.com

Iqrar A. Khan

mehtab89@yahoo.com

1 Institute of Horticultural Sciences, University of Agriculture Faisalabad, Faisalabad 38000, Pakistan

2 Centre of Agricultural Biochemistry and Biotechnology, University of Agriculture, Faisalabad 38000, Pakistan
$61.53 \%$ heterozygous allelic loci were determined. Primer mpdCIR48 produced a specific locus $(250 / 250)$ in all male samples whereas the same locus was absent in female samples. Similarly, a locus of $300 / 310$ bp reoccurred in 5 date palm male samples using marker DP-168 which indicated that these are the promising candidate marker to detect the sex in date palm seedlings at early stage. The data resulted from combination of 12 primers enabled the 16 seedling samples progeny (developed from parents breeding) of date palm cultivars to divide into two groups i.e., male and female regarding their sex expression comparative to the parents (male + female) using the principle coordinate analysis.

Keywords Phoenix dactylifera L. · SSR marker . Sex identification · Polymorphism

\section{Introduction}

Date palm $(2 n=36)$ is dioecious monocotyledonous belonging to Arecaceae family with 200 genera and 500 species (Dowson 1982). Phoenix is an important genus in the family which is most captivating (Munier 1973) as they exert great variation in their reproductive morphology, where single sex flowers are present on more than $85 \%$ palms (Dransfield et al. 2008). In Pakistan, it is the 3rd major fruit crop after citrus and mango, and about 325 varieties of date palm are reported (Botes and Zaid 2002).

Sex determination at early stages of growth is very important to facilitate the breeding programs. It is hard to differentiate the date palm sex at early stages, so one cannot employ the genetic diversity programs until it reached reproductive stage (5-10 years) (Bendiab et al. 1993). As date palm is dioecious, sex chromosomes are 
observed in homomorphic form. An extra-heterochromatin present on the both arms of the male chromosomes is considered to be sex determinant (Siljak-Yakovlev et al. 1996). Historically, an improved breeding program is lacking due to presence of low genetic diversity as simple and perfect method for gender differentiation before first flowering was absent (Aberlenc-Bertossi et al. 2011). Date palm progenies contain equal proportion of male and female plants which has been directed to the hypothesis that sex is found genetically (Daher et al. 2010). The sex chromosomes existence in date palm on the basis of cytological studies was proposed with chromomycin staining, however, the genes associated with sex have not been determined Siljak-Yakovlev et al. (1996). Similarly, the process of developmental stages that arrest the sterile sex organs has not been studied in detail. Using cytological and biochemical means, they concluded that there is no significant difference between male and female individuals and genetically its an important task to discriminate the sex agronomically in monoecious and dioecious species due to the longevity. Efforts have been made to understand the basic requirement of gender determination at early stage and use of the isozymes analysis (Torres and Tisserat 1980), peroxidases (Majourhat et al. 2002) and molecular marker tools with random amplified polymorphic DNA (RAPD) (Moghaieb et al. 2010).

Biochemical studies give in a little information for sex identification of immature plants and gender specific DNA sequences offer a more capable and efficient method for gender determination (Qacif et al. 2007). Various efforts had been made to comprehend the genetic basis of sex evaluation of plants at early stages of development with molecular tools (Biffi et al. 1995; Hormaza et al. 1994). Asparagus, Mercurialis, Vitis and Spinacia are the welldocumented examples in which sex identification was hindered due to the existence of additional factors and alleles that change the ultimate effect of sex determining genes (Durand and Durand 1990).

The recent techniques offer a new tool for genetic characterization and linkage maps construction with the use of polymerase chain reaction (PCR). 28,889 EST sequences from the date palm genome database were analyzed to identify simplesequence repeats (SSRs) and to develop gene-based markers, i.e. expressed sequence tagSSRs (EST-SSRs) (Zhao et al. 2013).

Arbitrary primers were used for the DNA template amplification in random amplified polymorphic DNA (RAPD) technique (Welsh and McClelland 1990). Very effective studies have been made on numerous plant species for linkage and evolution studies (Halward et al. 1992; Carlson et al. 1991). RFLPs and RAPD markers are effectively used for molecular studies of date palm (Abdallah et al. 2000; Trifi et al. 2000) to discriminate the sex-specific DNA with different molecular techniques (RAPD and ISSR) for the collection and reformation of outstanding male pollen. Molecular breeding would accelerate genetic improvement of fruit tree through marker-assisted selection. However, the lack of molecular markers in date palm restricts the application of molecular breeding.

In this study, we have identified the sex-specific DNA markers for date palm cultivars using microsatellites. Such a technique will not only facilitate the screening of gender at early developmental stage but also could be most important for speeding up breeding and, thereby, saving of time, cost and other resources.

\section{Materials and methods}

\section{Plant material and genomic DNA extraction}

Leaf samples of eight male and six female date palm trees were collected from two different locations of Horticultural Fruit Garden Square No. 9 and Square No 32 and Dera Ismail Khan while the leaves of 1-year-old progeny developed from hybridization of these parents were collected from the fruit plant nursery, University of Agriculture, Faisalabad, Pakistan (Table 3). The frozen young leaves were cleaned carefully with the distilled water to remove the waxy layer. Gene JET Plant Genomic DNA Purification Mini Kit was used to extract the DNA by following the manual instructions of the kit (Thermo Scientific). Quality of DNA was assessed by electrophoresis on $0.8 \%$ agarose gel and its quality and quantity was evaluated in Nanodrop ND-1000 spectrophotometer (Nanodrop Technologies, Wilmington, Dalware) to dilute DNA stock as $15 \mathrm{ng} / \mu \mathrm{L} \quad \mathrm{d}_{3} \mathrm{H}_{2} \mathrm{O}$ to use in PCR amplification.

\section{Microsatellite amplification}

Polymerase chain reaction (PCR) was carried out using $20 \mu \mathrm{L}$ of reaction mixture containing $2 \mu \mathrm{L}(10 \mathrm{ng})$ of total genomic DNA, $2 \mu \mathrm{L}$ of $10 \times$ buffer solution $\left[\left(\mathrm{NH}_{4}\right)_{4}\right.$ $\left.\mathrm{SO}_{4}\right] \mathrm{Mg}^{+}, 6.4 \mu \mathrm{L}$ of dNTPs $(5 \mathrm{mM}), 2.0 \mu \mathrm{L}$ of $\mathrm{MgCl}_{2}$ $(25 \mathrm{mM})$, Primer (Forward and Reverse) $10 \times$ from $100 \times$ (1.0 $\mu \mathrm{L}$ for each), Taq DNA polymerase 0.2 and $5.8 \mu \mathrm{L}$ of nuclease-free water. Amplification was carried out in veriti 96-well fast thermal cycler (Peq Lab) under the following conditions: initial DNA denaturation at $95^{\circ} \mathrm{C}$ for $10 \mathrm{~min}$, 35 cycles (denaturation at $95{ }^{\circ} \mathrm{C}$ for $30 \mathrm{~s}$, annealing temperature depending upon the primer for $30 \mathrm{~s}$ and extension at $72{ }^{\circ} \mathrm{C}$ for $1 \mathrm{~min}$ ) and final extension at $72{ }^{\circ} \mathrm{C}$ for $7 \mathrm{~min}$. Resolution of PCR products of 30 date palm parents and progeny amplified by 12 SSR primers were visualized by 
$6 \%$ denaturing polyacrylamide (PAGE) gel followed by ethidium bromide.

\section{Statistical analysis}

The bands of DNA fragments on SSR analysis were scored in a (0-1) binary format ( 0 for absence, 1 for presence) for allele(s) on respective locus. Efficacy and degree of polymorphism of reported SSR markers were assessed through power marker (Liu and Muse 2004) and principle component analysis for assessing genetic diversity between parents and progeny accessions was performed in PAST (Hammer and Khoshbakht 2005).

\section{Results and discussion}

The 12 primers examined in this study effectively generated clearly amplified SSR bands with different sizes ranging from $100 \mathrm{bp}$ with primer mpdCIR16 to $500 \mathrm{bp}$ with primer mpdCIR32 and mpdCIR57 (Table 1). The different band size range was reported by some other scientists like Ahmed and Al-Qaradawi (2009) and Zehdi et al. (2004b) who amplified the band size ranging from 100 to $300 \mathrm{bp}$ and 173 to $318 \mathrm{bp}$, respectively. Total 109 alleles were scored with a mean of 9.08 alleles per locus while allelic range varied from 5 to 16 with primers mpdCIR15 and mpdCIR57 (Table 1), whereas Elmeer and Mattat (2012) reported 3-13 alleles and average 4 alleles per locus was identified by Ahmad and Al-Qaradawi
(2009). In this study, more number of alleles appeared than previous studies which showed more polymorphism in Pakistani date palm cultivars; however, huge difference of Sudan cultivars may be due to difference of genotype in addition to more number of microsatellites (Durand and Durand 1990). Genetic diversity varied from 0.38 to 0.58 with a mean value 0.47 that is less than Sudanese date palm germplasm (0.70) Zehdi et al. (2004a) and Tunisian date palm, i.e. 0.853 (Elshibli and Korpelainen 2007). As all the progenies developed by hybridization, it is supposed that they shared common genetic basis. However, some progeny diverged from others due to mutational events that might occur during selection.

Sex determination is a fundamental and significant developmental process in the plant life cycle of all sexually reproducing plants and is economically very important. Sexual phenotypes in commercial crops dictate the method of cultivation and breeding. Long juvenile phase is an obstacle in date palm breeding progenies. Molecular tools have the promises to help out in discriminating male and female seedlings at their early growth stages.

All primers yielded the specific loci in male and female plants separately. These primers produced 15 polymorphic loci specifically in male date palm samples and the same DNA fragments were identified in date palm seedlings (Table 2), and the seedlings harboring the unique fragments were further characterized as male plants. Increasingly, $38.46 \%$ of these loci were scored as homozygous alleles (Table 2), while $61.53 \%$ were determined as heterozygous allelic loci. Male-6 was detected with

Table 1 SSR primers detail and summary of genetic diversity information by locus in date palm parents and progeny cvs. Hillawi and Khudrawy

\begin{tabular}{|c|c|c|c|c|c|c|c|c|}
\hline Sr. no & $\mathrm{PC}$ & AS & MAF & GN & AN & GD & $\mathrm{HZ}$ & PIC \\
\hline 1 & mPdCIR010 & $145-340$ & 0.51 & 18 & 15 & 0.58 & 0.31 & 0.50 \\
\hline 2 & mPdCIR015 & $140-190$ & 0.5 & 4 & 5 & 0.54 & 0.73 & 0.46 \\
\hline 3 & mPdCIR016 & $100-220$ & 0.55 & 10 & 9 & 0.51 & 0.33 & 0.40 \\
\hline 4 & mPdCIR025 & $210-320$ & 0.62 & 10 & 8 & 0.48 & 0.36 & 0.42 \\
\hline 5 & mPdCIR032 & $300-500$ & 0.67 & 9 & 9 & 0.43 & 0.4 & 0.34 \\
\hline 6 & mPdCIR035 & $190-275$ & 0.69 & 8 & 8 & 0.42 & 0.24 & 0.36 \\
\hline 7 & mPdCIR048 & $125-200$ & 0.74 & 5 & 5 & 0.39 & 0.28 & 0.33 \\
\hline 8 & mPdCIR057 & $80-500$ & 0.58 & 17 & 16 & 0.5 & 0.38 & 0.42 \\
\hline 9 & mPdCIR070 & $150-410$ & 0.65 & 13 & 10 & 0.45 & 0.38 & 0.38 \\
\hline 10 & mPdCIR085 & $180-400$ & 0.55 & 8 & 7 & 0.51 & 0.66 & 0.40 \\
\hline 11 & mPdCIR093 & $75-240$ & 0.7 & 9 & 9 & 0.38 & 0.35 & 0.32 \\
\hline 12 & DP168 & $190-300$ & 0.74 & 7 & 8 & 0.4 & 0.28 & 0.34 \\
\hline Total & & & 7.5 & 118 & 109 & 5.59 & 4.7 & 4.7 \\
\hline Mean & & & 0.63 & 9.83 & 9.08 & 0.47 & 0.39 & 0.39 \\
\hline
\end{tabular}

$P C$ primer code, $A S$ allele size, $M A F$ major allele frequency, $G N$ genotype number, $A N$ allele number, $G D$ genetic diversity, $H Z$ heterozygosity, $P I C$ polymorphic information contents 
Table 2 Homozygous and heterozygous allele (base pairs) markers which identified male date palm seedlings

\begin{tabular}{|c|c|c|c|c|c|c|c|c|c|}
\hline Sr. no. & Markers & M1 & M2 & M3 & M4 & M5 & M6 & M7 & M8 \\
\hline 1 & CIR10 & & $230 / 230$ & $335 / 340$ & $230 / 240$ & $230 / 240$ & & & \\
\hline 2 & CIR15 & & & $160 / 170$ & $160 / 170$ & $160 / 170$ & & $170 / 170$ & \\
\hline 3 & CIR16 & $190 / 190$ & & $180 / 180$ & & & & & \\
\hline 4 & CIR25 & $270 / 270$ & $270 / 270$ & & $270 / 270$ & $270 / 270$ & & $270 / 270$ & $270 / 270$ \\
\hline 5 & CIR32 & & $290 / 294$ & & $290 / 294$ & & & $290 / 294$ & \\
\hline 6 & CIR35 & & & & $240 / 235$ & $240 / 235$ & & $240 / 235$ & $235 / 235$ \\
\hline 7 & CIR48 & $250 / 250$ & $245 / 250$ & $245 / 250$ & $245 / 245$ & $245 / 250$ & $245 / 250$ & $245 / 250$ & $245 / 250$ \\
\hline 8 & CIR57 & & $295 / 295$ & $80 / 85$ & $80 / 85$ & & & & \\
\hline 9 & CIR70 & & & & $300 / 310$ & & & & $300 / 310$ \\
\hline 10 & CIR85 & & & & $160 / 162$ & & & & $160 / 162$ \\
\hline 11 & CIR93 & $170 / 175$ & & & & $170 / 175$ & & $170 / 175$ & \\
\hline 12 & DP168 & & $300 / 310$ & $300 / 310$ & $300 / 310$ & $300 / 310$ & $300 / 310$ & & \\
\hline
\end{tabular}

minimum number of markers, only two markers identified this male; however maximum in male- 4 where 10 markers out of 12 detected the male characters (Table 2). Microsatellite primers used in this study for sex identification at seedling stage were highly polymorphic and generated high number of alleles that confirmed the good transferability Billotte et al. (2004). Some primers had problematic loci that have already been reported for erratic amplification (Billotte et al. 2004; Ahmed and Al-Qaradawi 2009) and were excluded from the study, i.e. mPdCIR44 and mPdCIR78. In previous studies, mPdCIR48 did not amplify (Zehdi et al. 2004a, b; Henderson 2009) but in the present study this primer amplified successfully with low magnification.

In agriculturally important plants like date palm, kiwi fruit, pistachio and papaya, female trees produce the commercial crop while in asparagus, better quality harvest is obtained from male plants. So identification of such type of plants at early developmental stage is of great importance. Moreover, studies on dioecy through marker technology could provide better understanding for development (Ainsworth et al. 1998) and evolutionary pathways of dimorphism (Charlesworth and Charlesworth 1978; Charlesworth 1996).

Total 19 loci were scored from 12 primers which identified the male progeny and similarly 22 loci were recorded only in date palm using 14 primers (Elmeer and Mattat 2012) Increasingly, $42 \%$ of these loci were determined as homozygous while $58 \%$ were heterozygous allelic loci. Similarly, according to Al-Dous et al. 2011, 3.5 million SNP genotypes were identified and scanned in the date palm genome for male and female polymorphism that segregates with sex. They examined that same heterozygous genotypes were shared by the male genomes whereas female genome shared the similar homozygous genotypes (Table 3).

Primer mpdCIR48 produced a specific locus (250/250) in all male plants whereas the same locus was absent in female plants. Primer mpdCIR25 identified six male plants with a specific homozygous locus $270 / 270$. Similarly primer mpdCIR10 amplified two different fragments, one homozygous locus (230/230 bp) in male-2, while one heterozygous locus $(230 / 240)$ in male- 4 and male-5. The marker mpdCIR16 scored one homozygous fragment (190/ $190 \mathrm{bp}$ ) in male- 1 and another fragment of $180 / 180 \mathrm{bp}$ was identified in male-3. Primer mpdCIR25 characterized six male plants out of eight and a locus of $270 / 270 \mathrm{bp}$ was present in male samples of $1,2,4,5,7,8$. Likewise, mpdCIR32 amplified a specific fragment $290 / 294$ bp in three male samples. Three heterozygous loci were scored in male-4, 5 and 6 while a single homozygous locus (235/ $235 \mathrm{bp}$ ) was only amplified in male-8.

Great variations were observed in primer mpdCIR57, where a locus of $85 / 85$ bp was found in male- 3 and male- 4 and a fragment of $295 / 295$ bp was found in male- 2 that is the most promising locus to determine the male plants from the progeny. Moreover, primer mpdCIR70 differentiated the two male plants with a heterozygous locus 300/310 bp and a similar locus was identified in male-2, 3, 4, 5 and male- 6 with the primer DP-168. Following two allele sized $170 / 175$ bp amplified with primer mpdCIR 93 and 160/162 bp (exhibited by primer mpdCIR93) were repeated twice in male 4 and 7 , but these alleles were not observed in six female date palm trees. The data resulted from combination of 12 primers enabled the seedling samples of date palm cultivars to be divided into two groups regarding their sex expression (male and female) compared to their parents using the principle coordinate 
Table 3 Details of date palm parents and progeny along their collection site

\begin{tabular}{|c|c|c|c|}
\hline Sr. no. & Plants & Accession code & Collection site \\
\hline 1 & Male & M-1 Hillawi & Sq. No-9, UAF \\
\hline 2 & Male & M-2 Unknown & Sq. No-9, UAF \\
\hline 3 & Male & M-3 Unknown & Sq. No-9, UAF \\
\hline 4 & Male & M-4 Unknown & Sq. No-9, UAF \\
\hline 5 & Male & M-5 Khudrawi & Sq. No-9, UAF \\
\hline 6 & Male & M-6 Kurai & Dera Ismail Khan \\
\hline 7 & Male & M-7 Unknown & University Campus \\
\hline 8 & Male & M-8 Unknown & Sq. No-32, UAF \\
\hline 9 & Female & H-1 Hillawi & Sq. No-32, UAF \\
\hline 10 & Female & H-2 Hillawi & Sq. No-32, UAF \\
\hline 11 & Female & H-3 Hillawi & Sq. No-32, UAF \\
\hline 12 & Female & K-1 Khudrawi & Sq. No-32, UAF \\
\hline 13 & Female & K-2 Khudrawi & Sq. No-32, UAF \\
\hline 14 & Female & K-3 Khudrawi & Sq. No-32, UAF \\
\hline 15 & Progeny & HM-1 & Sq. No-32, UAF \\
\hline 16 & Progeny & HM-2 & Sq. No-32, UAF \\
\hline 17 & Progeny & HM-3 & Sq. No-32, UAF \\
\hline 18 & Progeny & HМ-4 & Sq. No-32, UAF \\
\hline 19 & Progeny & HM-5 & Sq. No-32, UAF \\
\hline 20 & Progeny & HM-6 & Sq. No-32, UAF \\
\hline 21 & Progeny & HM-7 & Sq. No-32, UAF \\
\hline 22 & Progeny & HM-8 & Sq. No-32, UAF \\
\hline 23 & Progeny & KM-1 & Sq. No-32, UAF \\
\hline 24 & Progeny & KM-2 & Sq. No-32, UAF \\
\hline 25 & Progeny & KM-3 & Sq. No-32, UAF \\
\hline 26 & Progeny & KM-4 & Sq. No-32, UAF \\
\hline 27 & Progeny & KM-5 & Sq. No-32, UAF \\
\hline 28 & Progeny & KM-6 & Sq. No-32, UAF \\
\hline 29 & Progeny & KM-7 & Sq. No-32, UAF \\
\hline 30 & Progeny & KM-8 & Sq. No-32, UAF \\
\hline
\end{tabular}

analysis (PCoA). Preferably Hamming distance was selected because, for shared characteristics it does not consider the common absence of alleles. For present study it was therefore considered to be most suitable, that included highly polymorphic data of microsatellite straddling policy at two levels. The PCoA suggested the total four broad groups comprising 8 male parents, 6 female parents, 11 male progenies and 5 female progenies. Trees are autonomous with $29 \%$ variations explained by first axis and $14 \%$ by the second axis. Figures 1 and 2 depict the variation within the parents, among the parents and the progeny. These findings are in accordance with the findings of date palm in Qatar (Elmeer and Mattat 2012). Male and female parents comprised separate groups while grouping of progeny into male and female fall between two parent groups that showed the sharing of alleles from both the parents and confirmed the true type hybridization. Male parents were found highly diverse from female parents and progeny. Among male parents, M8 and M5 were more divergent than other male plants, whereas the female sample number 20, 21 and 22 (H1, H2, H3) which belongs to same variety Hillawi, were closely compared with $\mathrm{K} 1$, $\mathrm{K} 2$, and $\mathrm{K} 3$ while K3 showed some genetic distances.

In date palm, limited numbers of suckers are produced, i.e., 15-20 throughout the female tree life, difficult to handle the large population, tedious and costly, need space and resources, so farmers are currently facing the problem to propagate from seeds. But farmers are unable to identify the gender of the date palm trees until it reaches the reproductive age (5-10 years) as this species is very slow flowering. The use of the flowering and vegetative characters (Rhouma 1994) and isozymes markers (Salem et al. 2001) are less productive as it takes a long time to evidence. So, fortunately SSR markers were used for 


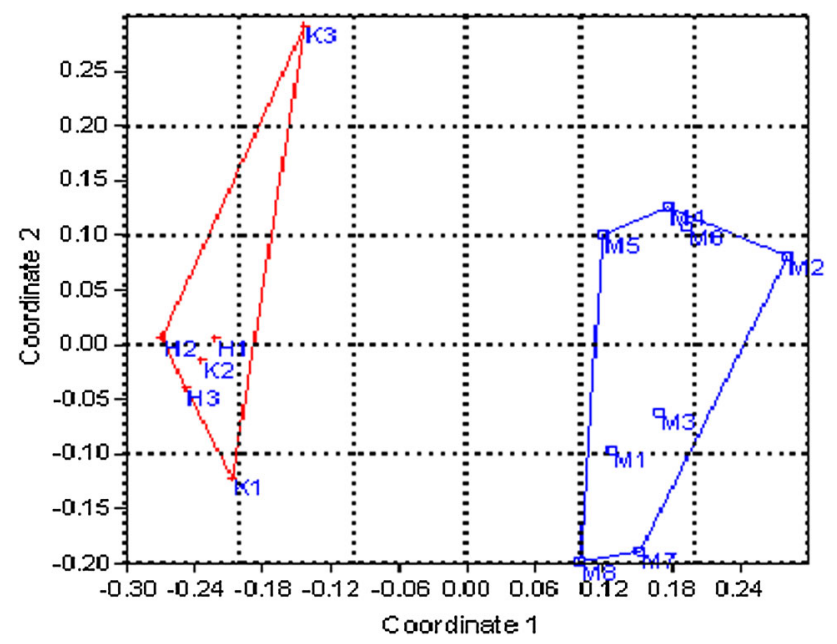

Fig. 1 Scatter plot of first and second principle coordinate analysis (PCoA) of male and female parents based on the SSR from 12 SSR primers

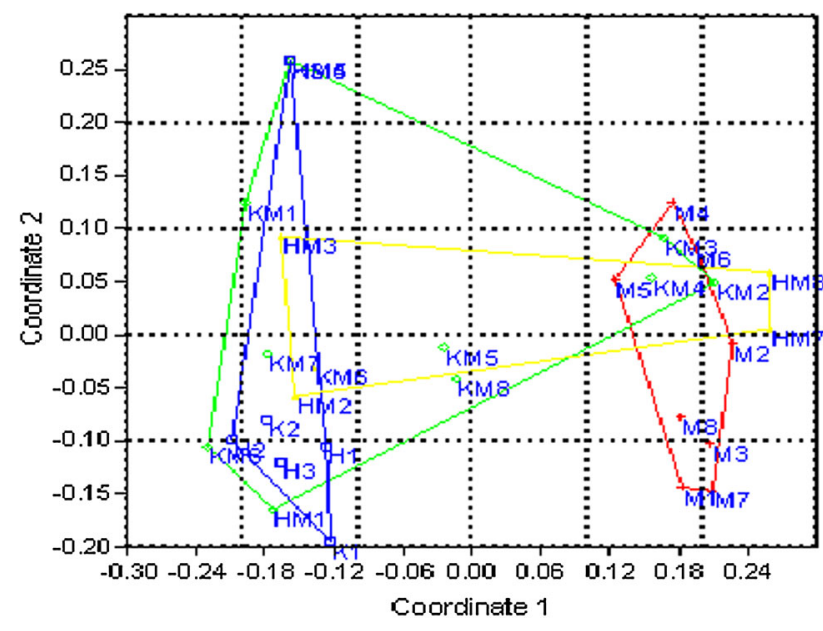

Fig. 2 Scatter plot of first and second principle coordinate analysis (PCoA) using hamming distance measures in convex hulls based on the SSR from 12 primers

molecular discrimination for unlimited date palm cultivars. This study is more precise and accurate compared to other date palm studies, i.e. plastid DNA halophytes (Sakka 2003) and isozymes (Salem et al. 2001; Booij et al. 1995). These data proved that SSR markers are more influential, powerful and key identifiers of date palm sex for speeding up the breeding programs.

\section{Conclusion}

Present study is the first comprehensive investigation on the sex identification of date palm seedlings with SSR markers from Pakistan. The 1-year-old date palm seedlings were characterized as male and female, and identified candidate markers involved in sex determination. This study will provide a substantial resource for speeding up the date palm breeding programs. These results will be helpful for an efficient screening, management and use of date palm genetic resources in selection and breeding program.

Acknowledgments Authors acknowledge financial support from Higher Education Commission (HEC), Goverment of Pakistan.

\section{Compliance with ethical standards}

Conflict of interest The authors declare that they have no conflict of interest in the publication.

Open Access This article is distributed under the terms of the Creative Commons Attribution 4.0 International License (http:// creativecommons.org/licenses/by/4.0/), which permits unrestricted use, distribution, and reproduction in any medium, provided you give appropriate credit to the original author(s) and the source, provide a link to the Creative Commons license, and indicate if changes were made.

\section{References}

Abdallah AB, Sitti K, Leporive P, Du Jardin P (2000) Identification de cultivars de palmier dattier (Phoenix dactylifera L.) par l'amplification aleatoire d'AND (RAPD). Cah Agric 9:103-107

Aberlenc-Bertossi F, Daher A, Chabrillange N, Tregear JW, Mohamed N (2011) Sex determination in date palm: new perspectives on an old theme. In: Plant and animal genomes XIX conference, W519: sex chromosomes and sex determination, Town and Country Convention Center, San Diego, CA, pp 15-19

Ahmed TA, Al-Qaradawi A (2009) Molecular phylogeny of Qatari date palm genotypes using simple sequence repeats markers. Biotechnology 8:126-131

Ainsworth C, Parker J, Buchanan-Wollaston V (1998) Sex determination of plants. Curr Top Dev Biol 38:167-223

Al-Dous EK, George B, Al-Mahmood ME, Al-Jaber MY, Wang H, Salameh YM, Al-Azwani EK, Chaluvadi S, Pantaroli AC, Debarry J, Arondel V, Ohlrogge J, Saie IJ, Elmeer KMS, Bennetzen JL, Kruegger RR, Malek JA (2011) De novo genome sequencing and comparative genomics of date palm (Phoenix dactylifera). Nat Biotechnol 29:521-528

Bendiab K, Baaziz M, Brakez Z, Sedra M (1993) Correlation of isoenzyme polymorphism and Bayoud-disease resistance in date palm cultivars and progeny. Euphytica 65:23-32

Biffi R, Restivo FM, Tassi F, Carboni A, Marziani GP, Sapda A, Falvigna A (1995) A restriction fragment length polymorphism probe for early diagnosis of gender in Asparagus officinalis L. HortScience 30:1463-1464

Billotte N, Marseillac N, Brottier P, Noyer JL, Jacquemoud-Collet JP, Moreau C, Covreur T, Chevallier MH, Pintaud JC, Risterucci AM (2004) Nuclear microsatellite marker for date palm (Phoenix dactylifera): characterization and utility across the genus Phoenix and in other palm genera. Mol Ecol Notes 4:256-258

Booij L, Montfort S, Ferry M (1995) Characterization of thirteen date palm (Phoenix dactylifera L.) cultivars by enzyme electrophoresis using the Phast System. J Plant Physiol 145:62-66 
Botes A, Zaid A (2002) Date production support program. FAO plant production and protection paper 156, Rev. 1. Food and Agriculture Organization of the United Nations, Rome, Italy

Carlson JE, Tulsieram LK, Glaubitz JC, Luk VWK, Kauffeldt C, Rutledge R (1991) Segregating of random amplified DNA markers in F1 progeny of conifers. Theor Appl Genet 83:194-200

Charlesworth B (1996) The evolution of chromosomal sex determination and dosage compensation. Curr Biol 6:149-162

Charlesworth B, Charlesworth D (1978) A model for the evolution of dioecy and gynodioecy. Am Nat 112:975-997

Daher A, Adam H, Chabrillange N, Collin M, Mohamed N, Tregear JW, Aberlenc-Bertossi F (2010) Cell cycle arrest characterizes the transition from a bisexual floral bud to a unisexual flower in Phoenix dactylifera. Ann Bot 106:255-266

Dowson (1982) Pollination and bunch management VIII (Date palm cultivation). FAO. pp 144-163

Dransfield J, Uhl NW, Asmussen CB, Baker WJ, Harley MM, Lewis CE (2008) Genera Palmarum, the evolution and classification of palms. Royal Botanic Gardens, Kew, UK

Durand R, Durand B (1990) Sexual determination and sexual differentiation. Crit Rev Plant Sci 9:295-316

Elmeer K, Mattat I (2012) Marker-assisted sex differentiation in date palm using simple sequence repeats. 3 Biotech 2:241-247

Elshibli S, Korpelainen H (2007) Microsallite markers reveal high genetic diversity in date palm (phoenix dactylifera L.) germplasm from Sudan. Genetica 134:251-260

Halward T, Stalker T, Larue E, Kochert G (1992) Use of singleprimer DNA amplifications in genetic studies of peanut (Aracbis bypogaea L.). Plant Mol Biol 18:315-325

Hammer K, Khoshbakht K (2005) Towards a 'red list' for crop plant species. Genet Resour Crop Evol 52:249-265

Henderson A (2009) Palms of Southern Asia. Princeton University Press, Princeton

Hormaza J, Dollo L, Polito V (1994) Identification of a RAPD marker linked to sex determinationin Pistacia vera using bulked segregant analysis. Theor Appl Gene 89:9-13

Liu K, S Muse (2004) Powermarker: new genetic data analysis software Version3.0. Free program distributed by the author over the internet from http://wwwPowermarker.ne

Majourhat K, Bendiab K, Medraoui L, Baaziz M (2002) Diversity of leaf peroxidases in date palm (Phoenix dactylifera L.) as revealed in an example of marginal (seedling derived) palm groves. Sci Hortic 95:31-38
Moghaieb REA, Abdel-Hadi AA, Ahmed MRA, Hassan AGM (2010) Genetic diversity and sex determination in date palms (Phoenix dactylifera L.) based on SSR markers. Arab J Biotechnol 13(2):143-156

Munier P (1973) Le palmier dattier. Techniques agricoles et productions tropicales. Maisonoeuvre et Larose edition, Paris, p 221

Qacif N, Baaziz M, Bendiab K (2007) Biochemical investigations on peroxidase contents of male and female inflorescences of date palm (Phoenix dactylifera L.). Sci Hortic 114:298-301

Rhouma A (1994) Le palmier dattier en Tunisie. I: le patrimoine génétique. Arabesque, Tunis, Tunisie

Sakka H (2003) Analyse de la diversité génétique chez le palmier dattier (Phoenix dactylifera L.): polymorphisme de l'AND chloroplastique. PhD thesis, Université de Tunis El Manar, Faculté de Science, Tunis, Tunisie 2003

Salem AOM, Trifi M, Sakka H, Rhouma A, Marrakchi M (2001) Genetic inheritance analysis of four enzymes in date-palm (Phoenix dactylifera L.). Genet Resour Crop Evol 48:361-368

Siljak-Yakovlev S, Cerbah M, Sarr A, Benmalek S, Bounaga N (1996) Coba de la Pena T, Brown SC: chromosomal sex determination and heterochromatin structure in date palm. Sex Plant Reprod 9(3): 127-132

Torres AM, Tisserat B (1980) Leaf isozymes as genetic markers in date palms. Am J Bot 67(2):162-167

Trifi M, Rhouma A, Marrakchi M (2000) Phylogenetic relationships in Tunisian date-palms (Phoenix dactylifera L.) germplasm collection using DNA amplification fingerprinting. Agronomie 20:665-671

Welsh J, McClelland M (1990) Fingerprinting genome-using PCR with arbitrary primers. Nucl Acid Res 18:7213-7218

Zehdi S, Sakka H, Rhouma A, Ali OMS, Marrakchi M, Trifi M (2004a) Analysis of Tunisian date palm germplasm using simple sequence repeat primers. Afr J Biotechnol 3:215-219

Zehdi S, Trifi M, Billotte N, Marrakchi M, Pintuad JC (2004b) Genetic diversity of Tunisian date palm (Phoenix dactylifera L.) revealed by the nuclear microsatellite polymorphism. Hereditas 141:278-287

Zhao et al (2013) Identification and characterization of gene-based SSR markers in date palm (Phoenix dactylifera L.). BMC Plant Biol 12:237 